Pak. J. Agri. Sci., Vol. 55(3), 555-562; 2018

ISSN (Print) 0552-9034, ISSN (Online) 2076-0906

DOI: $10.21162 / P A K J A S / 18.4493$

http://www.pakjas.com.pk

\title{
EFFECTS OF AFFORESTATION ON CARBON STOCKS IN FANDOGHLOO FOREST AREA
}

\author{
Ebrahim Fataei ${ }^{1, *}$, Saeid Varamesh ${ }^{2}$ and Seied Taghi Seiied Safavian ${ }^{2}$ \\ ${ }^{1}$ Department of Environmental sciences, Ardabil Branch, Islamic Azad University, Ardabil, Iran; ${ }^{2}$ Young \\ Researchers and Elite Club, Ardabil Branch, Islamic Azad University, Ardabil, Iran. \\ "Corresponding author's e-mail: ebfataei@gmail.com; ebfataei@iauardabil.ac.ir
}

\begin{abstract}
Afforestation of grasslands is increased in Fandoghloo region of northwestern Iran, which has been used for grazing. Carbon (C) stocking of pure and mixed Pinus nigra, Cedeus libani and Picea abies afforested stands (20 years-old) in Ardabil, Iran was assessed. C stocking of tree biomass and litter were defined based on plot-scale measurements. Soil organic carbon (SOC) stocking was determined using soil cores at three depths 0-15, 15-30 and 30-50 cm. An increase in the total ecosystem carbon stock after the afforestation was recorded. The highest total $\mathrm{C}$ stocking was estimated to be $55.57 \mathrm{Mg} \mathrm{ha}^{-1}$ for the mixed $P$. nigra - C. libani and it was $25.006 \mathrm{Mg} \mathrm{ha}^{-1}$ in the degraded rangeland. The aboveground biomass $\mathrm{C}$ varied from $2.4 \mathrm{Mg} \mathrm{ha}^{-1}$ in the degraded rangeland to $19.28,15.1,6.17,4.55$, and $3.87 \mathrm{Mg} \mathrm{ha}^{-1}$ in the P. nigra-C. libani, P.nigra, P. abies- P.nigra, C. libani and $P$. abies stands, respectively. The amount of litter carbon stock ranged from $0.53 \mathrm{Mg} \mathrm{ha}^{-1}$ in the degraded rangeland to $3.51,3.06,2.03,1.55,1.41 \mathrm{Mg} \mathrm{ha}^{-1}$ in the P. abies - P. nigra, P. nigra - C. libani, P. nigra, C. libani and P. abies stands, respectively. The soil carbon stock increased from 21.41 to $30.11,28.58,28.41,27.45$ and $25.43 \mathrm{Mg} \mathrm{ha}^{-1}$ in the $C$. libani, $P$. nigra, P. nigra - C. libani, P. abies - P.nigra and P. abies stands, respectively. Significant interactions were observed between stand and soil depth on carbon stock after afforestation with coniferous species in grassland. According to the results, the major ecosystem $\mathrm{C}$ pool is attributed to aboveground biomass. The total ecosystem $\mathrm{C}$ difference between the degraded rangeland and mixed P. nigra - C. libani stand was $30.56 \mathrm{Mg} \mathrm{ha}^{-1}$. The highest SOC accumulation was observed in the surface layer of the C. libani $\left(34.95 \mathrm{Mg} \mathrm{ha}^{-1}\right)$, but the accumulation rate is species dependent. The results highlighted the importance of coniferous afforestation on degraded grassland that will most presumably improve the amount of carbon stock and therefore, decrease the negative impacts of increasing $\mathrm{CO}_{2}$ concentrations. As a matter of fact, the selection of appropriate species and plantation will be considered in the next afforestation projects.
\end{abstract}

Keywords: Carbon stocking, pure and mixed afforestation, Pinus nigra, Cedeus libani, Picea abies, Fandoghloo.

\section{INTRODUCTION}

Nowadays humanity facing challenges at global level, resulting from climate change which is a consequence of increasing greenhouse gases, especially $\mathrm{CO}_{2}$ (Nakakaawa, 2010). Soil and tree biomass are reflected to have a large possibility for impermanent and a lot of time carbon storage (Houghton, 2005; Gower, 2003). Improvement of carbon stock by increasing the area of forested lands (afforestation) has been recommended as an efficient factor to reduce elevated $\mathrm{CO}_{2}$ agglomeration and thus provide to the prevention of global warming (Watson, 2000; IPCC, 2001). Some international organizations such as UNFCCC also encourage afforestation plans as an effective solution to decrease atmospheric carbon concentration (UNFCCC, 1997). The study of the impacts of tree plantation on the carbon stock is described by various researchers (Zinn, 2002; Lemma, 2006; Nosetto, 2006; Yuksek and Yuksek, 2011; Hansson 2013; Zhag, 2013; Varamesh, 2014), although the contribution of afforestation was known in biomass carbon stocking, the impacts of afforestation on soil carbon stock were less certain because of effective dynamic components such as rainfall, physico-chemical properties of soil, the age of planted stand (Guo and Gifford, 2002; Paul, 2002), but, the results of different studies regarding the afforestation effects are inconsistent in the case of on net SOC accretion. Therefore, more research needed to understand the accumulation potential of SOC under afforestation in degraded grasslands (Varamesh et al., 2014). The afforestation could be a very useful method for restoring degraded soils and ecosystems (IPCC, 2000) and in the global scale, this method is considered as soil conservation, desertification ,and an increase of carbon stock (Kumar et al., 2001; Maestre and Cortina, 2004; Nosetto et al., 2006). In a study, Giuffre et al. (2003) obtained significant differences by evaluating of soil organic carbon between the afforested regions compared with the rangeland in the Patagonia, Argentina. Nosetto et al. (2006) found that the afforestation with Pinus Ponderosa in grassland of Patagonia increases above -and belowground carbon stocks ,and Mireia (2010) noted a significant increase in soil organic carbon in the plantation of Pinus halepensis. Fonseca et al. (2012) found 
that biomass carbon was over $78 \mathrm{Mg}$ per hectare, but the soil characterizes the major carbon sink with more than $85 \mathrm{Mg}$ per hectare. Also, they estimated the values of above $5.3 \mathrm{Mg} / \mathrm{ha}$ and over $1.3 \mathrm{Mg} / \mathrm{ha}$ for mean annual carbon increases in the biomass and soil. Heras et al. (2013) claimed that in the shortterm, the carbon stored in the live biomass at afforested stand level was reduced, but the positive effect on productivity permits to restore and exceed the initial amount of carbon in the medium-term. Among the different ecosystems, coniferous forests were considered as great resources of carbon stocks (Gucinski et al., 1995). Several researchers (Akala and Lal, 2001; Xiao-Wen et al., 2009) have focused on the importance of afforestation and suitable species selection to enhance the carbon stocking. Thus, attention to forest ecosystem compartments contribution in carbon stocking is important, due to its necessity to recognize the potential of carbon stock of forest ecosystem to consider complex of trees, understory, soil and litter (Uri et al., 2012). The Pinus nigra, Cedrus libani, and Picea abies are known for afforestation in Iran. However, there are few studies about the effects of afforestation on the total carbon stock of ecosystem with these species in the degraded grasslands of Iran. As a result, definite purposes were to investigate the proportions of carbon stock in the compartments (soil, above - belowground biomass and litters) of coniferous planted stands and degraded grasslands, evaluate the depth pattern of soil organic carbon content at three depths, define the tendency and alterations in $\mathrm{C}$ pool of afforestation and determine the relationships of SOC with physico-chemical soil characteristics. The basic assumption of this study was relatively homogeneous biophysical conditions of the stands.

\section{MATERIALS AND METHODS}

Study area description: The Fandoghloo forest area is in the northwest of Iran (northeast of Ardabil), between latitudes $38^{\circ}$ $22^{\prime}$ to $38^{\circ} 24^{\prime} \mathrm{N}$ and longitudes $48^{\circ} 31^{\prime}$ to $48^{\circ} 34^{\prime} \mathrm{E}$ (Fig. 1). It is distributed over an area of 50 ha. The mean annual precipitation is $379 \mathrm{~mm}$ and the mean annual temperature is $8.8^{\circ} \mathrm{C}$. The elevation of the forested area ranges of 1350 to $1500 \mathrm{~m}$ above sea level. The study area including pure and mixed Pinus nigra, Cedeus libani and Picea abies afforested stands. In the past, afforested areas were barren land which was previously mainly used for grazing and were planted by the mentioned species almost 20 years ago. The soil texture of the area is loam and clay loam.

Sampling and inventory method of soil litter and trees: Surrounding rows of stands were not considered during sampling to avoid bordering effects (Varamesh et al., 2014). Using a randomly systematic method, sampling point of soil and litter pools were done in places where organic carbon accumulates to characterize carbon storage and distribution. Tree allometric equations were used to assess $\mathrm{C}$ accumulation in tree compartments. Field sampling and inventory in randomly systematic way was conducted during the October, (2013) using six squares $400 \mathrm{~m}^{2}\left(20-20 \mathrm{~m}^{2}\right)$ in each type of afforested system, i.e. Picea abies, Cedrus libani and Pinus nigra.

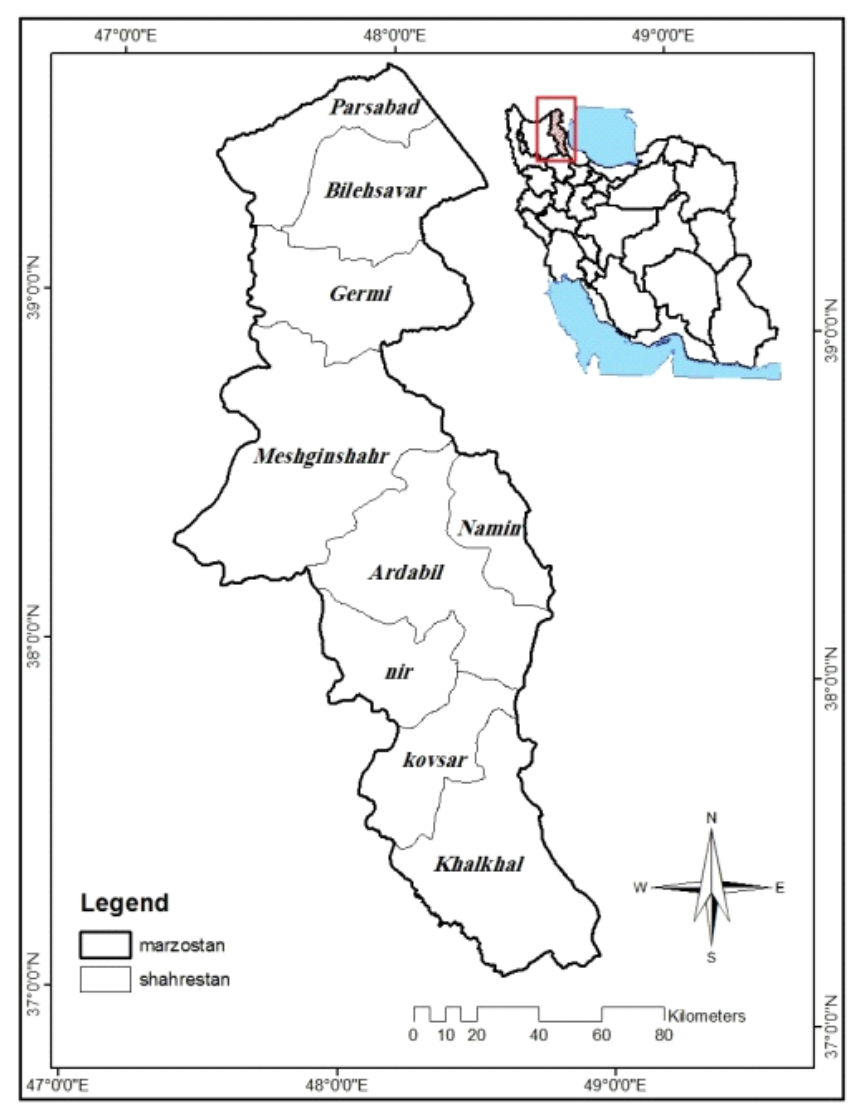

Figure 1. A general view and location of the study area in Ardabil Province and Iran.

Calculation of above and belowground biomass: In $20 \times 20$ $\mathrm{m}$ plots, quantitative properties like total height $(\mathrm{H})$, trunk height $(\mathrm{HC})$, diameter at breast height $(\mathrm{DBH})$ and two perpendicular diameters of the canopy (W \& L) of all tree species within the plot were measured. To calculate tree biomass and to compute trunk, canopy and root volume, the following steps were followed (Hernandez et al., 2004):

First, the basal area of tree was computed using equation 1 and then the tree volume was gained using equation 2. Finally, the biomass of trunk (kilogram) was computed according to the equation 3 .

$$
A b=\pi x r^{2}
$$

$r=$ the breast height radius of the tree, $\pi=3.14$

$$
V=A b \times H \times K c
$$

$\mathrm{Ab}=$ basal area, $\mathrm{H}=$ height, $\mathrm{Kc}=0.5463$

$$
\text { Biomass }=V \times W D \times 1000
$$

$\mathrm{V}=$ volume of the trunk, $\mathrm{WD}=$ wood density 
Since the full sampling of tree roots is time demanding and expensive and also in order to avoid destructive sampling methods, the root biomass was calculated using equation 4 (Hernandez et al., 2004)

$$
B G B=\text { Volume } A G B \times 0.2
$$

$\mathrm{BGB}=$ Below-Ground biomass $\quad \mathrm{AGB}=$ Above-Ground biomass

The canopy volume of trees was computed by the equation 5 .

$$
V \rrbracket m^{3}=\frac{\Pi \times D b^{2}}{12}
$$

Note: $\pi=3.14 \mathrm{Db}=$ diameter of the crown (to calculate $\mathrm{Db}$, the average of the field measurements $\mathrm{L}$ and $\mathrm{W}$ is taken and used as the diameter of the crown: $\mathrm{Db}=(\mathrm{L}+\mathrm{W}) / 2)$; $\mathrm{Hc}=$ height from the ground to the base of the crown.

The carbon Stock of biomass was calculated based on equation below

$$
\text { Biomass }_{\text {(total) }} \times \mathrm{C}=0.55
$$

Soil and litter sampling : Four soil profiles were dug in the four corners of the $400 \mathrm{~m}^{2}$ plot, then samples of soil were collected at three depths (0-15, 15-30, and 30-50 cm) (Lemma, et al., 2006; Uri et al., 2012), thus 72 soil samples were collected for each stand at three depths of soil. Bulk density of soil was characterized for calculation of the soil carbon, nitrogen and phosphorous storage. Thus, samples were taken from three soil depths $(0-50 \mathrm{~cm})$ using a stainless steel cylinder to avoid soil compacting and soil structure protecting (Uri et al., 2012). In each soil sample, litter and large plant material (e.g., root and shoots) were removed, then air dried and $2 \mathrm{~mm}$ sieved (Lemma, et al., 2006). The biomass of grass, shrubs and forbs species along with litter were collected in $0.25 \mathrm{~m}^{2}$ plots $\left(0.5 \_0.5 \mathrm{~m}^{2}\right)$. Sub samples were dried using oven and the values of dry matter coefficients were estimated and used to obtain dry matter from fresh weight.

Laboratory analyses: The value of bulk density was measured using dividing the oven-dried mass $\left(105^{\circ} \mathrm{C}\right)$ of the $<2 \mathrm{~mm}$ fraction. The Bouyoucos hydrometer method was used to determine the soil texture (Bouyoucos, 1962). The amount of soil $\mathrm{pH}$ was characterized potentiometrically in a 1:2.5 (v/v) soil:water suspension. EC was determined with (soil:water ratio, 1:2). The total $\mathrm{N}$ was measured using Kjeldahl. The soil phosphorus content was measured by flow injection method using Tecator ASTN 9/84 and total organic $\mathrm{C}$ determined according to the Walkey -Black technique.

The total soil carbon stock $\left(\mathrm{Mg} \mathrm{ha}^{-1}\right)$ within each soil depth was estimated using following relationship (Lemma et al., 2006).

Total soil carbon stock $\left(\mathrm{Mg} \mathrm{ha}^{-1}\right)=\mathrm{OC}\left(\mathrm{g} \mathrm{kg}^{-1}\right) . \varnothing \cdot \mu \cdot 10$ OC = Organic Carbon, $\varnothing$ is soil depth $(\mathrm{m}), \mu=$ bulk density $\left(\mathrm{Mg} \mathrm{m}^{-3}\right)$.

Statistical analysis: All of data were analyzed using the SPSS 19.0. The variable normality test was checked by the Kolmogorov- Smirnov; meanwhile, the equality of the variances was examined by the Levene's test.

The two-way analysis (ANOVA) was used to analyze the differences in soil properties among afforested stands and depths. Also, interactions between independent factors were

Table 1. Soil properties in stands and Rangeland.

\begin{tabular}{rcclllll}
\hline Soil & Depth & \multicolumn{7}{c}{ Stand } \\
\cline { 2 - 7 } properties & (cm ( & \multicolumn{1}{c}{ Pinus } & \multicolumn{1}{c}{ Cedrus } & Picea abies & Pinus-Cedrus & Picea- Pinus & grassland \\
\hline $\mathrm{PH}_{\mathrm{H} 2 \mathrm{O}}$ & $0-15$ & $5.63 \pm 0.03$ & $5.85 \pm 0.13$ & $5.49 \pm 0.058$ & $5.81 \pm 0.05$ & $5.51 \pm 0.0500$ & $5.53 \pm 0.07$ \\
& $15-30$ & $5.65 \pm 0.03$ & $5.40 \pm 0.026$ & $5.54 \pm 0.086$ & $5.83 \pm 0.12$ & $5.45 \pm 0.0100$ & $5.72 \pm 0.10$ \\
& $30-50$ & $5.50 \pm 0.03$ & $5.43 \pm 0.0066$ & $5.59 \pm 0.057$ & $5.62 \pm 0.07$ & $5.61 \pm 0.0057$ & $5.71 \pm 0.06$ \\
Bulk density & $0-15$ & $1.44 \pm 0.003$ & $1.51 \pm 0.0033$ & $1.49 \pm 0.030$ & $1.54 \pm 0.078$ & $1.41 \pm 0.003$ & $1.37 \pm 0.041$ \\
)g/cm ${ }^{-3}($ & $15-30$ & $1.51 \pm 0.003$ & $1.50 \pm 0.012$ & $1.55 \pm 0.041$ & $1.62 \pm 0.05$ & $1.31 \pm 0.006$ & $1.50 \pm 0.044$ \\
& $30-50$ & $1.61 \pm 0.009$ & $1.53 \pm 0.0003$ & $1.59 \pm 0.036$ & $1.46 \pm 0.015$ & $1.53 \pm 0.003$ & $1.57 \pm 0.050$ \\
)dS m${ }^{-1} \mathrm{EC}($ & $0-15$ & $0.023 \pm 0.0007$ & $0.0063 \pm 0.0012$ & $0.02 \pm 0.0023$ & $0.022 \pm 0.0006$ & $0.02 \pm 0.0007$ & $0.02 \pm 0.003$ \\
& $15-30$ & $0.031 \pm 0.0006$ & $0.0073 \pm 0.0003$ & $0.02 \pm 0.0026$ & $0.021 \pm 0.0037$ & $0.02 \pm 0.0003$ & $0.03 \pm 0.337$ \\
& $30-50$ & $0.018 \pm 0.0003$ & $0.011 \pm 0.0033$ & $0.02 \pm 0.0023$ & $0.021 \pm 0.0012$ & $0.01 \pm 0.0003$ & $0.03 \pm 0.003$ \\
Sand (\%) & $0-15$ & $25.67 \pm 0.3$ & $28.33 \pm 0.88$ & $33.42 \pm 1.82$ & $25.33 \pm 2.33$ & $26.33 \pm 0.33$ & $40.33 \pm 4.26$ \\
& $15-30$ & $29.67 \pm 0.3$ & $26.00 \pm 0.21$ & $33.75 \pm 2.25$ & $35.00 \pm 0.31$ & $29.00 \pm 0.58$ & $44.33 \pm 7.17$ \\
& $30-50$ & $29.67 \pm 2.18$ & $31.00 \pm 0.57$ & $32.92 \pm 2.43$ & $29.00 \pm 1.00$ & $29.33 \pm 0.33$ & $38.00 \pm 4.51$ \\
Clay (\%) & $0-15$ & $32.00 \pm 0.6$ & $31.00 \pm 0.57$ & $28.17 \pm 1.13$ & $32.33 \pm 1.20$ & $31.00 \pm 0.58$ & $23.67 \pm 0.33$ \\
& $15-30$ & $28.67 \pm 0.33$ & $30.67 \pm 0.66$ & $28.67 \pm 1.16$ & $28.33 \pm 0.33$ & $31.67 \pm 0.33$ & $21.00 \pm 1.00$ \\
& $30-50$ & $31.67 \pm 0.33$ & $27.33 \pm 0.33$ & $30.33 \pm 1.01$ & $32.67 \pm 1.20$ & $34.00 \pm 0.25$ & $22.33 \pm 2.60$ \\
Silt (\%) & $0-15$ & $42.33 \pm 0.7$ & $40.67 \pm 0.33$ & $38.42 \pm 1.81$ & $42.33 \pm 1.20$ & $42.67 \pm 0.33$ & $36.00 \pm 4.58$ \\
& $15-30$ & $41.67 \pm 0.33$ & $43.33 \pm 0.66$ & $37.58 \pm 1.42$ & $36.67 \pm 0.33$ & $39.33 \pm 0.67$ & $34.67 \pm 7.70$ \\
& $30-50$ & $38.67 \pm 1.85$ & $41.67 \pm 0.33$ & $36.75 \pm 2.14$ & $38.33 \pm 0.33$ & $36.67 \pm 0.33$ & $39.67 \pm 6.70$ \\
\hline
\end{tabular}

Values are means \pm SE of triplicate soil analysis. 
tested. The Duncan's test was employed to separate the averages of the dependent variables which were affected by treatment, significantly.

The physical and chemical characteristics of the soil samples are shown in Table 1 . The $\mathrm{pH}$ value of the soil $\left(\mathrm{H}_{2} \mathrm{O}, 1: 1\right)$ ranges from 5.43 to 5.85 and $\mathrm{EC}$ ranges from 0.1 to $0.0063 \mathrm{dS}$ $\mathrm{m}^{-1}$. Texture from loam in $p$. nigra stand to clay-loam in the other stands. The increase in bulk density with increasing depth was gained in more stands.

\section{RESULTS}

Some of the quantitative parameters of the stands are given in Table 2. Pure stand of P. nigra in most parameters had higher values compared to other stands. The highest amount of Trunk Height was in the C. libani and greatest canopy volume was observed in the P. nigra $-C$. libani.

Total carbon stock in the ecosyst: The total carbon stock of ecosystem has changed from $25.006 \mathrm{Mg}$ ha ${ }^{1-i n}$ degraded rangeland to $55.57 \mathrm{Mg} \mathrm{ha}^{-1}$ in the mixed $P$. nigra $-C$. libani, $49.01 \mathrm{Mg} \mathrm{ha}^{-1}$ in the $P$. nigra $38.7 \mathrm{Mg} \mathrm{ha}^{-1}$ in the mixed $P$. abies - P. nigra $37.84, \mathrm{Mg} \mathrm{ha}^{-1}$ in the pure C. libani and $31.68 \mathrm{Mg} \mathrm{ha}^{-1}$ in the pure P. abies stands (Fig. 2).

The carbon stock in the aboveground biomass showed significant increase after the afforestation in degraded rangeland ( $\mathrm{p}<0.001)$. (Fig. 2), so that it has increased from $2.4 \mathrm{Mg} \mathrm{ha}^{-1}$ in the rangeland to $19.2815 .1,6.17,4.55,3.87$ $\mathrm{Mg} \mathrm{ha}{ }^{-1}$ in the $P$. nigra $-C$. libani, $P$. nigra, $P$. abies $-P$. nigra, $C$. libani and $P$. abies stands, respectively (Fig. 2). The carbon stock in the belowground biomass showed significantly higher values after degraded rangeland afforestation in the all stands $(\mathrm{p}<0.001)$. So, it increased from $0.67 \mathrm{in}$ the degraded rangeland to $4.82,3.79,1.60,1.15,4.82$ and $10.97 \mathrm{Mg} \mathrm{ha}^{-1}$ in the P. nigra - C. libani, P. nigra, $P$. abies - P. nigra, $P$. libani and $P$. abies stands, respectively (Fig. 2). The carbon stock in the ecosystem litter had the same trend mentioned above .Therefore, a significant difference $(\mathrm{p}<0.001)$ was observed in the carbon stock which the values ranged from 0.53 in the rangeland to $3.07,2.027$, $1.55,1.41,3.51 \mathrm{Mg} \mathrm{ha}^{-1}$ in the P. abies - P. nigra, P. nigraC. libani, P. nigra, C. libani and P. abies stands, respectively (Fig. 2). The amount of carbon stock in the soils showed significant differences in the range of 21.41 in the rangeland and $30.11,28.58,27.45,25.4330 .11 \mathrm{Mg} \mathrm{ha}^{-1}$ in the C. libani, $P$. nigra, $P$. nigra - C. libani, $P$. abies $-P$. nigra and $P$. abies stands, respectively (Fig. 2). In general, the impacts of the degraded rangeland afforestation on the carbon stock in the ecosystem compartments showed significant difference increased .

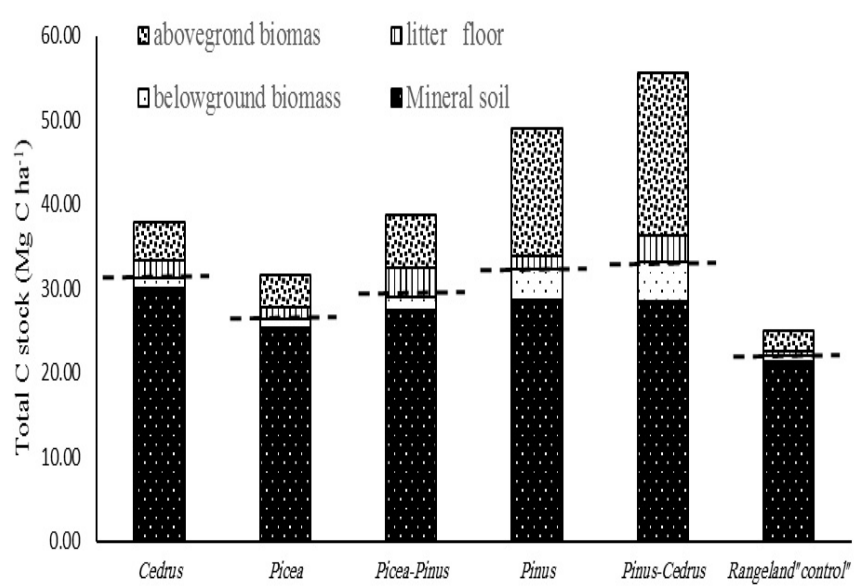

Figure 2. The amount of total $C$ (soil, litter, above and below ground) in each stand.

The carbon stock in the soil: After rangeland afforestation with coniferous species, significant $(\mathrm{p}<0.05)$ interactions were observed between stand and soil depth carbon stock. In general, the soil carbon stocks increased in all layers, (0$15 \mathrm{~cm}$, upper, $15-30 \mathrm{~cm}$, middle, and $30-50 \mathrm{~cm}$, lower layers) (Fig. 2). The highest carbon stock in the mineral soil was observed in the surface layer of the C. libani (34.95 $\mathrm{Mg} \mathrm{ha}^{-1}$ ), and in P. nigra stands with amount of 28.98 and $33.23 \mathrm{Mg} \mathrm{ha}^{-}$ 1 for middle and lower layers, respectively (Fig. 3). The carbon stock in the upper, middle and lower layer of each stand showed statistically significant differences among the P. nigra, P. abies - P. nigra, and C. libani stands (Fig. 3). The rangeland, $P$. nigra $-C$. libani and $P$. abies stands showed no significant differences in the depths considered. The rangeland afforestation effects on the carbon stock presented differences with the depth changes.

Table 2. Stand characteristics of the Pinus nigra, Cedrus, Picea abies, Pinus-Cedrus and Picea-Pinus stands.

\begin{tabular}{lccccc}
\hline Stand parameter & \multicolumn{4}{c}{ Stands } \\
\cline { 2 - 6 } & Pinus nigra & Cedrus & Picea abies & Pinus-Cedrus & Picea- Pinus \\
\hline DBH $(\mathrm{cm})$ & $17.27 \pm 0.305 \mathrm{a}$ & $12.47 \pm 0.018 \mathrm{~d}$ & $13.14 \pm 0.706 \mathrm{c}$ & $15.75 \pm 0.027 \mathrm{~b}$ & $15.67 \pm 0.088 \mathrm{~b}$ \\
Tree height $(\mathrm{m})$ & $7.61 \pm 0.315 \mathrm{a}$ & $6.25 \pm 0.123 \mathrm{~d}$ & $6.96 \pm 0.070 \mathrm{bc}$ & $6.73 \pm 0.093 \mathrm{~cd}$ & $7.28 \pm 0.041 \mathrm{ab}$ \\
Trunk Height $(\mathrm{m})$ & $3.17 \pm 0.018 \mathrm{~d}$ & $3.68 \pm 0.043 \mathrm{a}$ & $3.48 \pm 0.038 \mathrm{~b}$ & $3.28 \pm 0.006 \mathrm{c}$ & $3.28 \pm 0.015 \mathrm{c}$ \\
Canopy volume $\left(\mathrm{m}^{3} / \mathrm{ha}\right)$ & $9.72 \pm 0.069 \mathrm{~b}$ & $3.58 \pm 0.006 \mathrm{~d}$ & $6.54 \pm 1.094 \mathrm{c}$ & $12.49 \pm 0.012 \mathrm{a}$ & $5.73 \pm 0.033 \mathrm{c}$ \\
basal area $\left(\mathrm{m}^{2} / \mathrm{ha}\right)^{\text {Stand volume }\left(\mathrm{m}^{3} / \mathrm{ha}\right)}$ & $0.024 \pm 0.000 \mathrm{a}$ & $0.01 \pm 0.000 \mathrm{~d}$ & $0.013 \pm 0.001 \mathrm{~d}$ & $0.02 \pm 0.001 \mathrm{~b}$ & $0.018 \pm 0.000 \mathrm{c}$ \\
\hline
\end{tabular}

Values followed by the same letter within a row are not statistically different (Duncan, $\mathrm{P}<0.05$ ). 


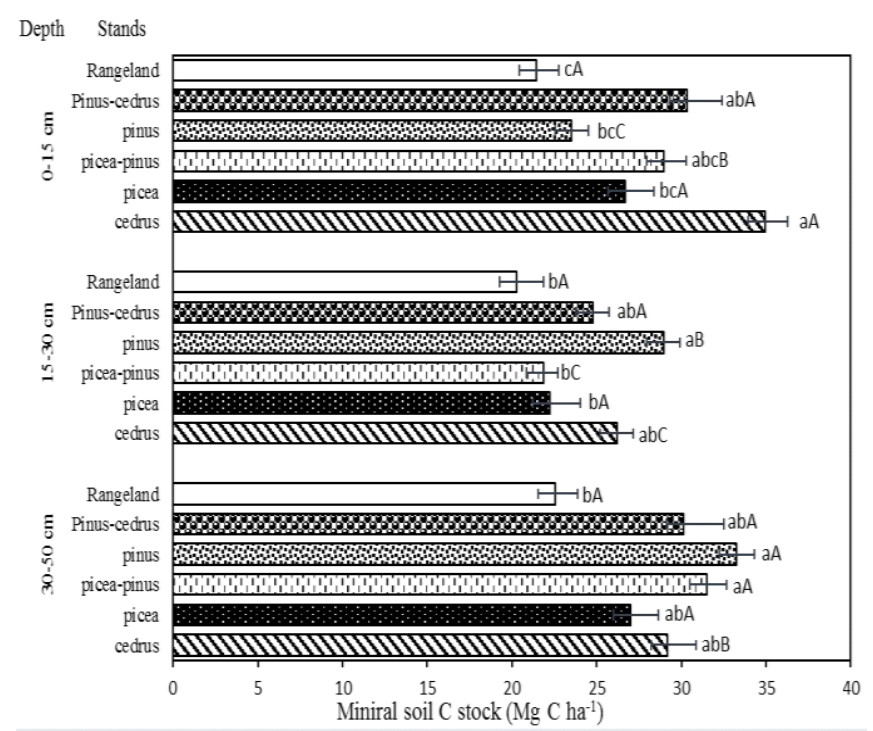

Figure 3. Soil C stocks distribution in stands (Mean \pm SE).

\section{DISCUSSION}

Establishment of coniferous species on the degraded grassland caused an increase in the carbon stock of ecosystem. Considering 20 years of establishment of coniferous species in the degraded grassland the amount of annual Carbon stocking in the mixed P. nigra $-C$. libani, $P$. nigra, mixed $P$. abies - P. nigra, pure $C$. libani, and $P$. abies stands were $1.60,1.26,0.72,0.67,0.35 \mathrm{Mg} \mathrm{C} \mathrm{ha-1} \mathrm{y}^{-1}$, respectively.

Main challenging issue was quantifying the soil and biomass carbon stock (Uri et al., 2012). The study revealed that carbon stock in the soil was higher than the other sections $(85.60$, 80.28, 79.58, 70.85, 58.30 and 51.11 in the P. abies, C. libani, $P$. abies - P. nigra, P. nigra, and P. nigra - C. libani stands, respectively. These results indicated the integral importance of soil in the carbon stocking of ecosystem. Peltoniemi et al. (2004) expressed that a significant amount of carbon was stored in the forest soils than the forest biomass. Similar results were described by Garten and Charles (2002).

According to the EC / UN-ECE (2003), the carbon stock of forest soils in Europe was 1/5 times more than biomass. In contrast, other studies indicated the high proportion of biomass in the total ecosystem carbon stock (Uri et al., 2012; De Wit et al., 2006; Peichl and Arain, 2006). Conflicting results on the soil carbon stock could be due to the influence of various factors on this matter. It was apparent that the type of tree species affected the carbon stock by the amount and quality of organic matter input by litter, root activity and microclimate change (Jandl et al., 2007; Lugo and Brown, 1993).

Also, Osher et al. (2003) expressed that the change of soil carbon stock associated with land use changes is in relation to soil mineralogy. In our study, it was found that the type of tree species had a direct impact on the carbon stock in the mineral sector of soil. Furthermore, a significant correlation was found among the clay, clay- silt, and soil carbon stock (Fig. 4a, c), while a significant negative correlation was found between the percentages of sand and soil carbon stock (Fig. 4b).

Bauer et al. (1987) believed that the soil organic carbon was related to the clay of soil. Garten (2002); Powers (2002) and Schlesinger et al. (2008) confirm our findings. They found that carbon stocking correlated with the silt and clay of soil. A high percentage of sand in the spruce stand (Table 1) could be a significant factor in the low carbon stock than the other stands. Rapid carbon aggregation and turnover in the Coarsegrained soils (Richter et al., 1999) could be effective to decrease the soil carbon stock in the pure spruce stand (Fig. 2) The clay and organic carbon were often formed as aggregate, and therefore they had much more affinity to bind organic matter compared to the sand (El Tahira et al., 2009). In this regard, Borchers and Perry (1992) observed that the concentration of organic matter was less in the sandy soils than the clay and silt soils.

In this study, different distributions of the soil organic carbon were determined in the soil layers of considered stands (Fig. 2). The increasing trend of carbon stock was observable in the pure pine (Fig. 2). Such a trend was seen to augment the bulk density with the increase of depth in this stand (Table 1). In general, a positive correlation between bulk density and the soil carbon stock was found in this study (Fig. 3d).

However, the differences in the amount of sand, clay and silt in the different depths could be the reason of different carbon distribution in the soil layers. The differences among tree species in the terms of the root activity region had remarkable impacts on these differences. The root decomposition (especially thin roots) was important processes affecting the density and carbon stock (Steele, 1997).

PH was one of the important soil properties which influenced the availability of the soil nutrients (Beery and Wilding, 1971) high soil $\mathrm{pH}$ in the surface soil layer of $C$. libani stand than other stands could cause to high mineral carbon stock of soil. Because there was the appropriate condition for degradation in the surface layer of this stand than the other stands which in turn increased the carbon stock in the higher levels of soil. Thuille and Schulze (2006) noted the decrease of fauna activity of acidic soil which could also result in high carbon stock in the surface layer of pine - cedar stand.

The litter production and its degradation had a significant effect on the soil fertility (Pragasan and Parthasaratly, 2005) and it was considered as a notable factor by which tree species could affect soil organic matter (Finzi, 1998). The high carbon stock in the biomass and litter on the forest floor in the mixed P. nigra - C. libani (Fig. 2) could significantly be due to the high significant canopy of this stand than the others. (Table 1). The litter resulted from trees were the main source of carbon in the forest ecosystems (De Marco, 2013) and the 

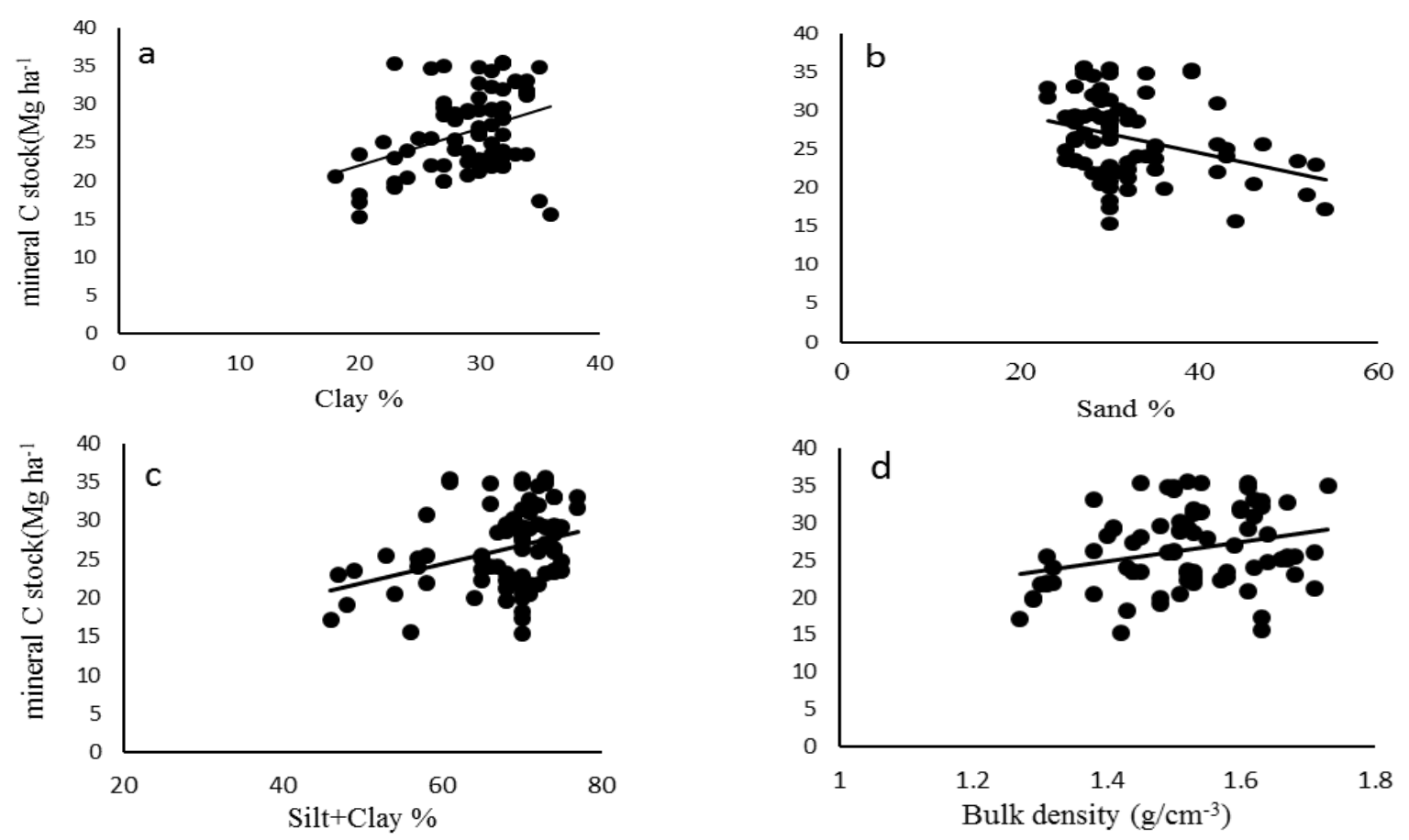

Figure 4. Correlation between $\mathrm{C}$ content $\left(\mathrm{Mg} \mathrm{ha}^{-1}\right)$ and Soil textural (Clay, Clay+silt and Sand) and bulk density. All are significant in 0.001 level except bulk density in level 0.05 density.

high canopy could be an integral source of litter and aboveground biomass in this stand. In total, 40.21 percent of the total carbon stock was in the aboveground P. nigra $-C$. libani stand. Accordingly, development of root would increase by the increase of canopy. In this stand, the highest belowground carbon stock included roots had significant difference than the other stands and it possessed 8.67 percent contribution of total carbon stocks of ecosystem.

In this study, the properties of species in the terms of growth of stem, branch, and leaf had significant impact on the rate of carbon accumulation in the above- and belowground biomass. In total, the amount of carbon accumulation in the coniferous ecosystems had significant increase in the degraded rangeland.

Conclusions: This study showed that the afforestation of degraded grasslands in the study area has a high potential of atmospheric carbon stocking and reduce the effect of high $\mathrm{CO}_{2}$ concentrations in a short time period. Biomass and soil $\mathrm{C}$ stocks differed depending on tree species. Further information may be worked out through the advance methodology extensive research and consideration of more factors in the future studies. Moreover, we can say that the maintenance or increase in carbon stock of forests has been linked to economic and external benefits, such as climate change mitigation, biodiversity improvement, water storage and regulation of local climate at landscape level.

\section{REFERENCES}

Akala, A. and R. Lal. 2001. Soil organic carbon pools and stocking rates in reclaimed mines oils in Ohio. $\mathbf{J}$. Environ. Qual. 30:2098-2104.

Bauer, A., C.V. Cole and A.L.Black. 1987. Soil property comparisons in virgin grasslands between grazed and non-grazed management systems. Soil Sci. Soc. Amer. J. 51:176-182.

Beery, M. and L.P. Wilding. 1971. The relationship between soil $\mathrm{pH}$ and base-saturation percentage for surface and subsoil horizons of selected mollisols, alfisols, and ultisols in Ohio. Ohio J. Sci. 71:43-55.

Borchers, J.G. and D.A. Perry. 1992: The influence of soil texture and aggregation on carbon and nitrogen dynamics in southwest Oregon forests and clear cuts. Can. J. For. Res. 22:298-305.

Bouyoucos, G.J. 1962. Hydrometer method improved for making particle size analysis of soils. Argon. J. 6:464465.

De Marco, A., F. Esposito, B. Berg, M. Giordano and A. Virzo De Santo. 2013. Soil C and N stocking in organic and mineral layers of two coeval forest stands implanted on pyroclastic material (Mount Vesuvius, South Italy). Geoder. 209:128-135.

De Wit, H.A., T. Palosuo, G. Hylen and J. Liski. 2006. A carbon budget of forest biomass and soils in southeast 
Norway calculated using a widely applicable method. For. Ecol. Manage. 225:15-26.

de Vries, W., G.J. Reinds, M. Posch, M.J. Sanz, Krause, Calatayud, V., G.H.M. J.P. Renaud, J.L. Dupouey, H. Sterba, H.M. Vel, M. Dobbertin, P. Gundersen and J.C.H. Voogd. 2002. Intensive monitoring of forest ecosystems in Europe. Technical Report EC/UN-ECE 2002, Brussels, Geneva; p.163.

El Tahira, B.A., D.M. Ahmedb, J. Ardo, A.M. Gaafard and A.A. Salih. 2009. Changes in soil properties following conversion of Acacia senegal plantation to other land management systems in North Kordofan State, Sudan. J. Arid Environ. 73:499-505.

Fataei, E., S. Varamesh, B. Behtari and S.T. Seyyed Safavian. 2013. Soil carbon and nitrogen stocks under Pinus nigra and Cedrus libani afforestation in the Northwestern Highlands of Iran. Adv. Environ. Biol. 7:4316-4325.

Finzi, A.C., C.D. Canham and N. Van Breemen. 1998. Canopy tree soil interactions within temperature forests: Species effects on $\mathrm{pH}$ and cations. Ecol. Appl. 8:447-454.

Garten, Jr. and T. Charles. 2002. Soil carbon storage beneath recently established tree plantations in Tennessee and South Carolina, USA. Biomass Bioener. 23:93-190.

Giuffre, L., O. Heredia, C. Pascale, D. Cosentino, M. Conti and E. Schnug. 2003. Land use and carbon stocking in arid soils of northern Patagonia (Argentina). Landbauforsch. Volk. 53:13-18.

Gower, S.T. 2003. Patterns and mechanisms of the forest carbon cycle. Ann. Rev. Environ. Resour. 28:169-204.

Grunzweig, J.M., T. Lin, E. Rotenberg, A. Schwartz and D. Yakir. 2003. Carbon stocking in arid-land forest. Glob. Change Biol. 9:791-799.

Gucinski, H., E. Vance and W.A. Reiners. 1995. Potential effects of global climate change. In: W.K. Smith and T.M. Hinckley (eds.), Ecophysiology of Coniferous Forests. Academic Press, New York; pp.309-331.

Guo, L.B. and R.M. Gifford. 2002. Soil carbon stocks and land use change: a meta analysis. Glob. Change Biol. 8:345-360.

Hansson, K., M. Fröberg, H.S. Helmisaari, D.B. Kleja, B.A. Olsson, M. Olsson and P. Tryggve. 2013. Carbon and nitrogen pools and fluxes above and below ground in spruce, pine and birch stands in southern Sweden. For. Ecol. Manage. 309:28-35.

Hernandez, R., P. Koohafkan and J. Antoine. 2004. Assessing carbon stocks and modeling win-win scenarios of carbon stocking through land-use changes. Food and Agriculture Organization; pp.166-168.

Houghton, R.A. 2005. Aboveground forest biomass and the global carbon balance. Glob. Change Biol. 11:945-958.

IPPC. 2000. Land use, Land-Use Change and Forestry. Cambridge University Press, Cambridge; p.375.
IPCC. 2001. Climate Change Mitigation. Available online at http://www.grida.no/climate/ipcc_tar/wg3/pdf/TARtotal.pdf

Jandl, R., M. Lindner, L. Vesterdal, B. Bauwens, R. Baritz, B. Hagedorn, D.W. Johnson, K. Minkkinen and K.A. Byrne. 2007. How strongly can forest management influence soil carbon stocking? Geoder. 137:253-268.

Kumar, S., R. Datta, S. Sinha, T. Kojima, S. Katoh and M. Mohan. 2001. Carbon stock, afforestation and acidic deposition: an analysis of inter-relation with reference to arid areas. Water Air Soil Pollut. 130:1127-1132.

Lemma, B., D. Berggre, I. Nilssonc and M. Olsson. 2006. Soil carbon stocking under different exotic tree species in the southwestern highlands of Ethiopia. Geoder. 136: 886898.

Lugo, A.E. and S. Brown. 1993. Management of tropical soils as sinks or sources of atmospheric carbon. Plant Soil 149:27-41.

Maestre, F.T. and J. Cortina. 2004. Are Pinus halepensis plantations useful as a restoration tool in semiarid Mediterranean areas? For. Ecol. Manage. 198:303-317.

Matus, F.J., C.H. Lusk and C.R. Maire. 2008. Effects of soil texture, carbon input rates, and litter quality on free organic matter and nitrogen mineralization in Chilean rain forest and agricultural soils. Comm. Soil Sci. Plant Anal. 39:187-201.

McDicken, K. G. 1997. A guide to monitoring carbon storage in forestry and agro forestry projects. Winrock International Institute for Agricultural Development, Forest Carbon Monitoring Program; p.91.

Mireia, L., G.M. Bruno and T. Belén. 2010. Storage of organic carbon and black carbon in density fractions of calcareous soils under different land uses. Geoder. 159:31-38.

Nosetto, M.D., E.G. Jobbágy and J.M. Paruelo. 2006. Carbon stocking in semi-arid grasslands: Comparison of Pinus ponderosa plantations and grazing exclusion in NW Patagonia. J. Arid Environ. 67:142-156.

Osher, L.J., P.A. Matson and R. Amundson. 2003. Effect of land-use change on soil carbon in Hawaii. Biogeochem. 65:213-232.

Paul, K.I., P.J. Polglase, J.G. Nyakuengama and P.K. Khanna. 2002. Change in soil carbon following afforestation. For. Ecol. Manage. 168:241-257.

Peichl, M. and M.A. Arain. 2006. Above- and belowground ecosystem biomass and carbon pools in an age-sequence of temperate pine plantation forests. Agric. For. Meteor. 140:51-63.

Peltoniemi, M., R. Makipaa, J. Liski and P. Tamminen. 2004. Changes in soil carbon with stand age- an evaluation of a modelling method with empirical data. Glob. Change Biol. 10:2078-2091. 
Powers, J.S. and W.H. Schlesinger. 2002: Relationships among soil carbon distributions and biophysical factors at nested spatial scales in rainforests of northeastern Costa Rica. Geoder. 109:58-62.

Pragasan, L.A. and N. Parthasarathy. 2005. Litter production in tropical dry evergreen forests of south India in relation to season, plant life forms and physiognomic groups. Curr. Sci. 88:1255-1263.

Richter, D.D., D. Markewitz, S.E. Trumbore and C.G. Wells. 1999. Rapid accumulation and turnover of soil carbon in a re-establishing forest. Nature 400:56-58.

Steele, S.J., S.T. Gower, J.G. Vogel and J.M. Norman. 1997. Root mass, Root mass, net primary production and turnover in aspen, jack pine and black spruce forests in Saskatchewan and Manitoba, Canada. Tree Physiol. 17:577-587.

Thuille, A. and E.D. Schulze. 2006. Carbon dynamics in successional and afforested spruce stands in Thuringia and the Alps. Glob. Change Biol. 12:325-342.

Uri, V., M. Varik, J. Aosaar, A. Kanal, M. Kukumägi amd K. Lõhmus. 2012. Biomass production and carbon stocking in a fertile silver birch (Betula pendula Roth) forest chronosequence. For. Ecol. Manage. 267:117-126.

United Nations Framework Convention on Climate change (UNFCCC). 1997. Kyoto protocol to the United Nations framework convention on climate change. Available online http://unfccc.int/resource/docs/convkp/kpeng.htlm.
Varamesh, S, S.M. Hosseini, N. Abdi and M. Akbarinia. 2010. Effects of afforestation on soil carbon stocking in an urban forest of arid zone in Chitgar forest park of Tehran. For. Sci. 3:75-90.

Varamesh, S., S.M. Hosseini and N. Abdi. 2011. Estimating potential of urban forests for atmospheric carbon stocking. J. Environ. Stud. 37:113-120.

Varamesh, S., S.M. Hosseini, F.K. Behjou and E. Fataei. 2014. The impact of land afforestation on carbon stocks surrounding Tehran, Iran. J. For. Res. 25:135-141.

Watson, R.T. 2000. Land Use, Land-Use Change, and Forestry: A Special Report of the IPCC. Cambridge University Press, Cambridge; p.77.

Xiao-Wen, D., H. Shi-Jie, H. Yang-Ling and Z. Yu-Mei. 2009: Carbon and nitrogen transformations in surface soils under Ermans Birch and Dark coniferous forests. Pedosph. 19:230-237.

Yüksek, T. and F. Yüksek. 2011. The effects of restoration on soil properties in degraded land in the semi-arid region of Turkey. Catena 84:47-53.

Zhang, C., F. Liu, S. Xue and C. Sun. 2013. Soil organic carbon and total nitrogen storage as affected by land use in a small watershed of the Loess Plateau, China. Eu. J. Soil Biol. 54:16-24.

Zinn, Y.L., D.V.S. Resck and J.E. Silva. 2002. Soil organic carbon as affected by afforestation with Eucalyptus and Pinus in the Cerrado region of Brazil. For. Ecol. Manage. 166:285-294. 